\title{
Challenges Facing the Planning of Higher Education in Federal Capital Territory, Abuja, Nigeria
}

\author{
Ogunode Niyi Jacob ${ }^{1}$ \\ ${ }^{1}$ Federal University Wukari, Nigeria \\ ${ }^{1}$ ogunodejacob@gmail.com
}

\begin{abstract}
Planning of Higher institutions in Nigeria and in Federal Capital Territory, Abuja, Nigeria has always been confronted with many challenges. This purpose of this study was to investigate the challenges facing planning of higher institutions in Federal Capital Territory, Abuja, Nigeria. A descriptive research method was adopted for the study. The total numbers of hundred (100) respondents were selected from various agencies and ministry of education using stratified and systematic sampling technique with the use questionnaires to collect information from respondents who participated in the study. The data collected were carefully analyzed using percentages supported by chi-square to represent the raw data in a meaningful manner. The questionnaire was validated by two lecturers from University of Abuja department of educational administration. Two research questions and one hypothesis were developed for the study. Test-retest reliability was employed for the study. Result collected and analyzed revealed that there is significant relationship between planning of higher institutions and challenges. This result also showed that political influence, political instability, inadequate data, inadequate fund to plan, pressure group, inadequate planning and poor capacity of planner are the challenges facing the planning of higher institutions. The paper recommends that the government should increase the budgetary allocation for educational planning in the country.
\end{abstract}

Keywords: planning, educational planning, higher institution

\section{Introduction}

Federal Ministry of Education (2004) defines tertiary education as the education given after secondary education in Universities, Colleges of Education, Polytechnics, Monotechnics, as well as those institutions offering correspondence courses. According to Adeyemi (2001), Higher Education refers to a system which embraces much of the country's research capacity and reproduces majority of the skilled professionals that are required in the labour market. Obanya (1999) views higher education thus "Higher Education is taken to embody all organized learning and training activities at the tertiary level. This includes conventional universities, those with the conventional arts, humanities and science faculties as well as specialized universities like institutions specializing in agriculture, engineering, science, and technology. It also includes post-secondary institutions such as the polytechnics and colleges of education. "Higher Education" includes all forms of professional institutions drawing from the available pool of persons who have completed a various forms of secondary school education: Institution of the military, the police, nurses, agriculture, forestry, veterinary workers, catering services, tourism, secretarial services and other 
possible combinations of programmes. Even this wide spectrum does not exhaust the possibilities of forms of Higher Education...... such as non formal higher education. Indeed, any situations in which mature persons are organized for building up their knowledge and skills, to apply knowledge to the analysis and search for solutions to life problems."

According to the National Policy on Education the following are aims of higher education in Nigeria:

1. the acquisition, development and inculcation of the proper value orientation for the survival of the individual and societies;

2. the development of the intellectual capacities of individuals to understand and appreciate environment;

3. the acquisition of both physical and intellectual skills which will enable individuals to develop into useful members of the community;

4. the acquisition of an overview of the local and external environments (Federal Ministry of Education, 2004).

The National Policy on Education again stated that higher educational institutions should pursue these goals through:Teaching, Research, the dissemination of existing and new information, the pursuit of service to the community; and by being a store- house knowledge (Federal Ministry of Education, 2004).

Higher educational institutions in Nigeria from their modest beginning are expected to offer services that significantly contribute within the context of a sound macro-economic and political environment to the growth of the society. From a global perspective, economic and social developments are increasingly driving the advancement and application of knowledge.

Education in general and higher education in particular, are fundamental to the construction of a knowledge economy and society in all nations. The nation looks up to higher education to through its traditional functions of teaching, research and community service to develop manpower and disseminate necessary knowledge that are needed in industry and other sectors. The Nigeria higher education system comprised of universities, polytechnics, and colleges offering programmes in teacher education and agriculture. Higher education is a community of scholars, free to pursue knowledge without undue interference from anywhere (Noun, 2007).

The Federal Ministry of Education is the government body that directs education in Nigeria. The Minister of the FME is appointed by the President. Functions of the FME include formulating a national policy on education, collecting and collating data for purposes of educational planning and financing, maintaining uniform standards of education throughout the country, and controlling the quality of education in the country through the supervisory role of its Inspectorate Services Department. The FME harmonizes educational policies and procedures of all the states of the federation through the instrumentality of the National Council on Education. It also effects cooperation in educational matters on an international scale. The FME coordinates the activities of a number of parastatals under it such as the National Universities Commission (NUC), the National Commission for Colleges of Education (NCCE), the National Board for Technical Education (NBTE) and the Universal Basic Education Commission (UBEC) (NEEDS, 2014). 
Universities produce high-level manpower in various fields. There are conventional universities that produce graduates in the fields of pure and applied sciences and arts. There are also specialized universities that produce graduates in their areas of specialization. In the latter category, there are technology universities, agriculture universities and one military university. By the end of 2013, there were 129 universities in Nigeria, of which 40 were federal-owned, 39 were state-owned and 50 were private (Moja, 2000).

Polytechnics train middle-level technical manpower. They award national certificates and diplomas, namely: the National Diploma (ND), awarded after two years of study following the senior secondary school; and the Higher National Diploma (HND), awarded after a further two-year course. Students are expected to have at least one year industrial attachment after obtaining the ND and before pursuing the HND course. As at the end of 2013, there were 81 polytechnics in Nigeria recognized by the National Board of Technical Education. Twenty-one of the polytechnics were owned by the Federal Government, 38 by state governments, and 22 by private individuals or organizations (NEEDS, 2014).

Colleges of education produce middle manpower in teacher education. The colleges, under the supervision of the National Commission for Colleges of Education, offer three-year programmes. Those who finish the programme earn the Nigeria Certificate in Education (NCE), which is the minimum teaching qualification in the country. As at 2013, there were 21 federal, 43 state-owned, 24 privately owned colleges of education in the country. In addition, the National Teachers Institute and some polytechnics in the country offer teacher education programmes for an NCE qualification. Furthermore, all conventional universities offer teacher education programmes for a bachelor's degree in education with majors in different teaching subjects (NEEDS, 2014).

The responsibility for administering the education sector in Nigeria is shared among the federal, state and local governments. Thus, in the country's constitution, education is on the concurrent list, but the Federal Government is empowered to regulate all its sectors, engage in policy formation and ensure quality control. Also, the provisions of the constitution allow each tier of government to focus its responsibilities mainly on a sector of education. The Federal Government is involved directly in tertiary education. The states take care of secondary education, while the local governments handle primary education. Despite this arrangement, the Federal Government is expected to support the state and local governments in counterpart funding to enhance the quality of education in the country (NEEDS, 2014).

The planning and administration of the education system is shared mainly among the education ministries at the federal and state levels, as well as statutory bodies referred to as commissions. There are commissions established for different subsectors of the education system and are charged with various responsibilities for the subsectors. The FME is responsible for the coherence of the national policy and procedures and for ensuring that the states' policies operate within the parameters of the national policy as adapted for local needs (Moja, 2000). Coordination of policy at the political level is handled by the National Council of Education, the highest policymaking body chaired by the Federal Minister of Education and includes all the State Commissioners of Education. This body is advised by the Joint Consultative Committee on Education, which consists of all the Federal and State Directors of Education, Chief Executives of education statutory bodies, and Directors of University Institutes of Education. 
The policy for higher education in Nigeria is embedded in the National Policy on Education. So also other issues approved from time to time by the National Council on Education (NCE) which is the highest decision making body on education related matters. Again, are the other policies legislated and passed into law in respect of higher education operations and management in the country. The policy for higher education in Nigeria is based on what the government approves as the practice to be promoted in Nigeria or what the government of the day legislates within the overall goal of higher education.

Higher education is under the supervision of commissions set up by law and which operate as parastatals of the FME. For instance, universities are supervised by the National Universities Commission (NUC), while colleges of education are supervised by the National Commission for Colleges of Education (NCCE). The National Commission for Colleges of Education (NBTE) oversees polytechnic education. These commissions are responsible for policy decisions affecting institutions under their supervision, maintenance of standards through a system of periodic accreditation of courses, distribution and monitoring of government funding, appointment of members of governing councils, and the day-to-day running of the institutions (NEEDS, 2014).

Abuja is the capital of Nigeria. The City is host to many higher institutions. The private higher institutions are spread across the city while the public higher institutions are located in the southern part of the City. The majorities of the higher institutions located in FCT, Abuja are faced with many challenges such as shortage of staff, inadequate infrastructural facilities, over-crowded lecturer halls and inadequate funds. Noun (2007) submits that Nigeria's higher education is beset more by evidences of systemic maladies rather than salutary breakthroughs. The predicaments commonly characteristic of Nigerian higher institutions of learning since the 1980s, and especially in the $1990 \mathrm{~s}$ and in this 21st century include obvious inadequacy of funding; low staff motivation; the brain drain syndrome; disproportionate staff-student ratio; and scanty research feats. The educational malpractices easily identified in higher institutions are examination fraud; students versus host community clashes; cultism; students' indecent dress code; drug abuse; violent behaviour and sexual harassment; shallow teaching; financial exploitation of students by lecturers; among others. All this problems are traced to lack of effective planning of higher education in the country and in FCT in Particularly. It is based on this submission that the purpose of this study is to investigate the challenges facing planning of higher education in Federal Capital Territory, Abuja, Nigeria.

\section{Planning}

According to Longe (2003), planning implies given thoughts to the goals, aspirations and priorities of a nation. Planning involves examining the future and drawing up a course of action for attaining specific goals. It means working out in broad outline the things to be done and the procedures for doing them to accomplish set purpose (Akpan, 2000). Dror (1963) defined planning as "the process of preparing a set of decisions for action in the future and directed at achieving goals by optional means". Planning is intelligent preparation for action. It is a process of deciding in advance what to do, how to do it, when to do it and who should do it. It bridges the gap from where we are and where we want to go. Planning is therefore, future-oriented. It is concerned with the future and involves predicting the effect of future events so that hindrances of the present could be minimized or eliminated in order 
to meet the future with more confidence and success (Akpan, 2000). According to Aghenta (1993), planning can be simply described as the process of drawing or sketching an object on a flat surface just like the earliest form of building plans. Planning is a process of designing of a project or programme to be executed for a purpose. Therefore, planning is the first activity that should precede Implementation. Planning is a deliberate and organized process. It is also rational and continuous. Planning can be carried out by individuals, organizations and corporate bodies. Planning can be classified into

Micro-Level Planning: This is concerned with any planning activity that is carried out at local government or institutional level, that is, the school level. It includes the planning activities by the Local Education Authority, School Managers, and teachers concerning facility planning, time-tabling, time scheduling and curriculum planning.

Macro-Level Planning: This involves policy making, resource allocation and target setting at state, national and international levels.

However, the above classifications apply to all kinds of planning in organizations. The kinds of planning include:

(a) Educational planning

(b) Physical planning

(c) Academic planning

(d) Town and Regional planning

(e) Development planning

(f) Economic planning

(g) Social planning

(h) Curriculum planning etc. (Noun, 2007a)

\section{The Concept of Educational Planning}

Adepoju (2000) defines educational planning as the process of identifying educational needs and the direction education should take and how to implement decisions. This means that educational planning must reflect the state of development of a nation, including its needs and the readiness to execute the planned objectives. Educational planning can be view as a process of making deciding the future goals and how the goals will be achieved. Coombs (1970) cited in (Akpan, 2000) views educational planning as the application of rational systematic analysis to the process of educational development with the aim of making education more effective and efficient in responding to the needs and goals of the students and the society. This definition connotes that planning of education should take cognizance of the learners' needs in the areas of learning facilities and equipment, textbooks, classroom spaces and qualified educational personnel. In terms of meeting the needs of the society, educational planning should take cognizance of the manpower, cultural, social and communication needs of the society (nation) as well as the economic changes (Akpan, 2000).

Educational planning therefore, must take into account the population growth of children of school age in relation to educational opportunities and the demand for education. Educational planning should take into account political, economic and social changes going 
on in the society as well as technological changes. It is therefore, a blue-print that gives direction for future educational development and prescribes the direction and course of actions for the accomplishment of set educational goals and objectives (Akpan, 2000).

Educational planning should focus on:

1. Identifying educational needs of the nation

2. Setting realistic educational goals and objectives.

3. Formulating a set of policies and decisions to guide implementation.

4. Prescribing the means (action plan) to achieve set goals and objectives.

5. Providing strategies for monitoring and evaluation of progress

6. Providing appropriate channels for feedback and review

Education planning today, according to Ogundele (2004), is faced with numerous challenges that required more sophisticated and better planning approaches to succeed. Some of these challenges bordered on curriculum structure, decision implementation, leadership and environmental constraint, implementation of academic programmes are carried out without in-depth analysis of problems and challenges they are expected to address. Education plans and decision implementation channel are taken in haphazard manner without proper initiatives. In other words, there is so much of whims and caprices approach to education programme planning and implementation in schools.

James \& Victor (2015) observes that adequate consideration and planning on the factors like curriculum relevance, students enrolment, manpower development school plant maintenance, school finance management and staff/personnel matters both at the planning and implantation stages and which are indices of academic programme execution and successful implantation are given very poor attention in the schools. While, these schools plan their growth rate in future, it is not too clear whether at the stage of planning, due consideration is given to the cost implications of the envisaged academic programme expansion (Amuchie, Asotibe, \& Christina, 2013). A review of related literature has revealed that attempts in the past to provide free education whether at the federal or state levels has never been successful due to poor planning and implementation. This view was supported by Ogunode (2009) who sees poor planning as one of the problems responsible for the unsuccessful implementation of the former UPE programme. They posited that the planners of the programme were unable to project fairly accurate number of children that would gain from the scheme.

According to Adarnaechi \& Romaine (2000) proper planning has been found to be the root of the success of every good educational policy or programme Without proper planning, the best education programme is bound to fail The UPE programme of the past suffered from lack of planning.

Institutional and system planning is critical for the restoration of quality in the system.

The plans developed must be linked to realistic budget plans. Through planning, issues of uncontrolled growth in the number of students, programs, and institutions, could be addressed. Regional and national development needs could be met through regional collaboration as well as by improvement of efficiency of the system. Edame (2015) also stated that dissipated effort, wasted resources, and poor results often accompany poor 
planning (Moja, 2000). Planning, supervision and monitoring mechanisms for the entire education system have been very weak. Management problems within the system have been cited often as a factor that impacts negatively on the success of projects that have been supported by international development agencies.

Otive (2017) Observes that the challenge is that since return to civil rule in 1999, there has been a lot of sporadic and adhoc planning without adherence to long term planning. Study shows that there are several factors responsible for the declining public service quality in Nigeria. The factors include poor planning; policy discontinuities, reversals and somersault; lack of participatory, open, transparent and inclusive budgeting; diversion of public funds; poor human resource management and poor performance management. Nwachukwu (2013) Submits that the Nigerian educational system has undoubtedly encountered a number of significant impediments in the last few decades and it continue to struggle with the implementation and assurance of educational and teaching quality because of lack of effective planning. A shortage of accurate statistical data, financial, qualified planners, poor national economic performance, unsuitable governing structures, political interference, and general instability have all contributed to low quality in educational planning.

\section{Research Gap}

Several studies have been carried out in regard of higher education. Ekundayo \& Ajayi (2009) observe that Higher education plays a crucial role in the supply of high level manpower for the socio-political and economic development of a nation. To this end, the effective management of this educational sector becomes necessary. Their paper examines the myriads of problems militating against the effective management of the Nigeria university education system. These include: financial crisis, poor infrastructure, brain-drain, erosion of university autonomy, graduate unemployment, volatile and militant students' unionism, secret cults, examination malpractices and sexual harassment. Therefore, it is recommended that government should re-address the issue of funding of university, review upward the pay-package of academics, grant the university autonomy and make plans and projections on the nation's manpower needs in a bid to integrate this into the university programmes.

Mahabub (2014) submits that access to university education in Nigeria has become a serious issue due to sector's inability to provide an equal access to students that result in lowering the rate of student enrolment in higher education. Mahabub's (2014) paper examines the issues entailing the education sector of Nigeria and inhibiting the process of providing equal access to university education. The research investigation shows that Nigerian Education sector is facing multiple issues related to administrative, social and infrastructural domains, few of the issues are, limited carrying capacity, quota system, inadequate fund, poor economic background of students, and absence of technology. To address these issues research recommends that introducing eLearning will enhance student's access to education and its cost effectiveness will equally bring access to economically or culturally restricted sector of Nigerian populace. ELearning is the most effective response to current educational access challenges and should be immediately pursued to achieve the positive outcomes in enhancing equal access to universities. Charles \& Chukwugozie (2016) observe in their study that a look at Nigeria's national policy on education on tertiary or higher education reveals a startling chasm of gap between the goals 
of the policy through General Studies Programme and their expected actualizations. This problem, that is, the chasm of gap, is owned to the maladministration and immoral conducts of the people to whom the students are under their influence directly or indirectly. It is the effects of these chasms of gap that have resulted largely in unemployable youths in Nigeria's labour market per se, youth's restiveness and so many other ills that go with it. In this study, through the philosophical method of critical analysis, the researchers are poised to offer competent administration born of patriotism and good moral conducts on the part of higher institutions' hierarchies as valuable ideas that will bridge the existing gap between the goals of the policy and their expected actualizations, and as such, yield the desired results.

Boniface, Alfred, \& Dieudonné (2019) did a study to determine the relationship between monitoring and evaluation (M\&E) practices and academic staff motivation in higher education, from a Rwandan perspective. Particularly, the study aimed at describing the M\&E practices applied, assessed how quality of feedback affects academic staff motivation, and determined the relationship between M\&E practices and academic staff motivation. The study employed a mixed-methods approach to collect data from academic staff. A total of 105 faculties were sampled. The study established that M\&E practices, including staff selfevaluation, students-staff evaluation, peer evaluation, and evaluation by supervisor, are applied at varying emphasis. Furthermore, both the supervisees and supervisors agreed that the quality of feedback provided during evaluation is fairly effective, although recognition of their performance is rarely appreciated. It was further established that weak to moderate correlations exist between M\&E practices and academic staff motivation with " $r$ " varying from 0.268 to 0.4460 . Although some indications for the direction of influence have been generated, the study, however, does not permit one-way final conclusion about the effect of any of the M\&E practices to academic staff motivation. Based on the findings, this study recommends that policy makers design a policy on $M \& E$, which would guide supervisors in $M \& E$ exercise. It is obvious from the above literature reviewed on higher education that there is a research gap on planning of higher education. In order to cover this research gap, this study is aimed to investigate the challenges facing planning of higher institutions in Federal Capital Territory, Abuja, Nigeria.

\section{Research Objectives}

The objective of this study is to investigate the challenges facing planning of higher institutions in Federal Capital Territory, Abuja, Nigeria. Specific objectives are to:

1. To establish if there are challenges facing planning of higher education.

2. To find out the challenges facing the planning of higher education.

Research Question The following research question where generated to guide this study:

1. Are there challenges facing planning of higher education?

2. What are the challenges facing planning of higher education?

Research Hypothesis Based on the research questions raised, the following hypothesis were developed to give direction to the study: There is no significant relationship between challenges and planning of higher education.

\section{Method}


The empirical data for the study were collected through questionnaires. The study population covers educational planners in various agencies and ministry of education in Abuja. Purposive and convenience sampling methods were adopted in selecting participants for this study. Purposive in the sense that only educational planners in charge of higher education were used and convenience in the sense that educational planner in different offices who created time in responding to the questionnaires in Abuja were used. The research instrument was divided into two sections, the first tends to obtain the respondent bio-data while the second part contains the items regarding the constructs of the subject matter and this was based on a four-point Likert scale (4-Strongly Agreed, 3- Agree, 2Strongly Disagree, 1-Disagree) that best describes the extent to which the respondents agree with each items in the questionnaire. The questionnaire was validated by two lecturers from University of Abuja department of educational administration. Two research questions and one hypothesis were developed for the study. Test-retest reliability was employed for the study. The methods that were used to analyze the data in this work was descriptive methods of analysis. The opinions of the respondents on each question are weighed using simple percentage. This is done so as to ascertain the average opinion of the respondents. A total of 60 questionnaires were administered within the scope of selected location, having sorted the returned questionnaires, the final valid sample size for the analysis was 60 .

\section{Results}

Research Question one: Are there challenges facing planning of higher education?

Table 1. Responses on if there are there challenges facing planning of higher education?

\begin{tabular}{|l|l|l|l|l|l|l|l|l|}
\hline S/N & Items & $\begin{array}{l}\text { Strongly } \\
\text { Agree }\end{array}$ & Agree & $\%$ & Disagree & $\begin{array}{l}\text { Strongly } \\
\text { Disagree }\end{array}$ & $\%$ & Total \\
\hline 1 & $\begin{array}{l}\text { There are there } \\
\text { challenges facing } \\
\text { planning of higher } \\
\text { education }\end{array}$ & $41(41 \%)$ & $37(37 \%)$ & $78 \%$ & $12(12 \%)$ & $10(10 \%)$ & $22 \%$ & 100 \\
\hline
\end{tabular}

Reaction from research question one table one item one showed that $41(31 \%)$ of the respondents strongly agreed, $37(37 \%)$ of the sampled respondents agreed while $11(11 \%)$ disagreed and $10(10 \%)$ strongly disagreed that there are challenges facing planning of higher institutions. This implies that the majorities of the respondents agreed that there are challenges facing planning of higher institutions.

Research Question two: What are the challenges facing planning of higher education?

Table 2. Responses on challenges facing planning of higher education

\begin{tabular}{|l|l|l|l|l|l|l|l|l|}
\hline S/N & $\begin{array}{l}\text { The following are } \\
\text { the challenges } \\
\text { facing planning of } \\
\text { higher institutions }\end{array}$ & $\begin{array}{l}\text { Strongly } \\
\text { Agree }\end{array}$ & Agree & $\%$ & Disagree & $\begin{array}{l}\text { Strongly } \\
\text { Disagree }\end{array}$ & $\%$ & Total \\
\hline 1 & Political influence & $32(32 \%)$ & $41(41 \%)$ & $73 \%$ & $17(17 \%)$ & $10(10 \%)$ & $17 \%$ & 100 \\
\hline 2 & Political instability & $37(37 \%)$ & $33(33 \%)$ & $70 \%$ & $18(18 \%)$ & $12(12 \%)$ & $30 \%$ & 100 \\
\hline 3 & Inadequate data & $51(51 \%)$ & $31(31 \%)$ & $82 \%$ & $12(12 \%)$ & $6(6 \%)$ & $18 \%$ & 100 \\
\hline 4 & $\begin{array}{l}\text { Inadequate fund to } \\
\text { plan }\end{array}$ & $36(36 \%)$ & $28(28 \%)$ & $64 \%$ & $24(24 \%)$ & $12(12 \%)$ & $36 \%$ & 100 \\
\hline 5 & Pressure group & $45(45 \%)$ & $35(35 \%)$ & $80 \%$ & $12(12 \%)$ & $8(8 \%)$ & $20 \%$ & 100 \\
\hline 6 & $\begin{array}{l}\text { Inadequate } \\
\text { planning }\end{array}$ & $47(47 \%)$ & $31(31 \%)$ & $78 \%$ & $13(13 \%)$ & $9(9 \%)$ & $22 \%$ & 100 \\
\hline
\end{tabular}




\begin{tabular}{|l|l|l|l|l|l|l|l|l|}
\hline 7 & $\begin{array}{l}\text { poor capacity of } \\
\text { planner }\end{array}$ & $42(42 \%)$ & $38(38 \%)$ & $80 \%$ & $14(14 \%)$ & $6(6 \%)$ & $20 \%$ & 100 \\
\hline
\end{tabular}

On weather if political influences is a problem, result collected from research question two table two item one showed that $32(32 \%)$ of the respondents strongly agreed, $41(41 \%)$ of the sampled respondents agreed while $17(17 \%)$ disagreed and $10(10 \%)$ strongly disagreed that political influence is one of challenges facing planning of higher education. This implies that the majorities of the respondents agreed that political influence is one of challenges facing planning of higher education.

To find out if political instability is a problem, Result on two table two item two showed that $37(37 \%)$ of the respondents strongly agreed, $33(33 \%)$ of the sampled respondents agreed while $8(18 \%)$ disagreed and $12(12 \%)$ strongly disagreed that political instability is one of challenges facing planning of higher education. This implies that the majorities of the respondents agreed that political instability is one of challenges facing planning of higher education.

Result from research question two table two item three showed that $51(51 \%)$ of the respondents strongly agreed, $31(31 \%)$ of the sampled respondents agreed while $12(12 \%)$ disagreed and 6(6\%) strongly disagreed that inadequate data is one of challenges facing planning of higher institutions. This implies that the majorities of the respondents agreed that inadequate data is one of challenges facing planning of higher institutions.

Data obtained from research question two table two item four showed that $36(36 \%)$ of the respondents strongly agreed, $28(28 \%)$ of the sampled respondents agreed while $24(24 \%)$ disagreed and $12(12 \%)$ strongly disagreed that inadequate fund to plan is one of challenges facing planning of higher institutions. This implies that the majorities of the respondents agreed that inadequate fund to plan is one of challenges facing planning of higher institutions.

Result from research question two table two item five showed that $45(45 \%)$ of the respondents strongly agreed, $35(35 \%)$ of the sampled respondents agreed while $12(12 \%)$ disagreed and $8(8 \%)$ strongly disagreed that pressure group is one of challenges facing planning of higher institutions. This implies that the majorities of the respondents agreed that pressure group is one of challenges facing planning of higher institutions.

Table two item six result showed that $47(47 \%)$ of the respondents strongly agreed, $31(31 \%)$ of the sampled respondents agreed while $13(13 \%)$ disagreed and $9(9 \%)$ strongly disagreed that inadequate planning is one of challenges facing planning of higher institutions. This implies that the majorities of the respondents agreed that inadequate planning is one of challenges facing planning of higher institutions.

The result from table two item seven disclosed that that $42(42 \%)$ of the respondents strongly agreed, $38(38 \%)$ of the sampled respondents agreed while $14(14 \%)$ disagreed and $6(6 \%)$ strongly disagreed that poor capacity of planner is one of challenges facing planning of higher institutions. This implies that the majorities of the respondents agreed that poor capacity of planner is one of challenges facing planning of higher institutions.

\section{Hypothesis Testing}

HO There is no significant relationship between planning of higher institutions and challenges. 
$\mathrm{H} 2$ There is significant relationship between planning of higher institutions and challenges.

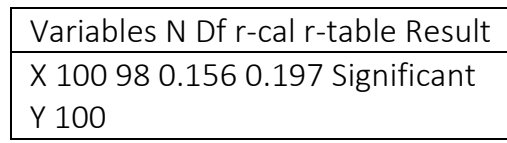

The table above showed that the $r$ calculated is 0.197 , which is greater than the $t$ calculated of value 0.156 . This means that there is significant relationship between planning of higher institutions and challenges.

\section{Discussion}

Result from table one item one revealed that there are challenges facing planning of higher education in FCT. This implies that the majorities of the respondents agreed that there are challenges facing planning of higher institutions.

Table two item one result showed that political influence is one of challenges facing planning of higher institutions. This implies that the majorities of the respondents agreed that political influence is one of challenges facing planning of higher institutions. This result supported the finding of Nwachukwu (2013) who disclosed that the existing political arrangement has influenced the control over educational planning in Nigeria. Political instability have had its toll on educational programmes. Planning process started by one administration is brutally interrupted by the next and the differences between federal and state government education policies are quite challenging. The inability of the Nigerian political structure does not allow for education planners to be accountable for their wrong doings.

Result from research question two table two item two showed that political instability is one of challenges facing planning of higher institutions. This implies that the majorities of the respondents agreed that political instability is one of challenges facing planning of higher institutions. Ade (2003) identified politics as having tremendous influence on Universities in Nigeria. This could be as a result of political Instability particularly during the Military era. The Nigerian society is made up of different political parties. At any time in point that a political party comes to power, it tries to keep to its own agenda or campaign promises. Hence, the ruling party tends to lack the political will to fund, carry out the programme of activities outside its agenda and therefore no continuity.

Two table two item three indicated that inadequate data is one of challenges facing planning of higher institutions. This implies that the majorities of the respondents agreed that inadequate data is one of challenges facing planning of higher institutions. Moja (2000) observes that any analysis of the Nigerian education sector is particularly challenging due to the lack of adequate data. Most of the literature available only provides information up to the midnineties. Data available was primarily for the eighties or early nineties. Data on the education system have not been collected in a timely manner or processed in a way that is adequate for planning. The system has thus suffered from lack of adequate planning for the implementation of the policies that are vital to improved quality and expansion.

Result from research question two table two item four showed that inadequate fund to plan is one of challenges facing planning of higher institutions. This implies that the majorities of the respondents agreed that inadequate fund to plan is one of challenges 
facing planning of higher institutions. Ogunode (2009) submits that planning budget or funds allocated for planning programme in Nigeria have been low for some years now. The budgetary allocations that get to the agencies and ministries for planning is nothing to write home about (Nwachukwu, 2013). Opines that funds provide for education planning is too small for proper planning to take place. The condition of the sector remains a thing of concern. Under-funding and systemic corruption makes the matter worse. The insufficient funding of the education planning sector stands as one of the major factors working against effective planning and implementation of education programmes.

Table two item five result disclosed that pressure group is one of challenges facing planning of higher institutions. This implies that the majorities of the respondents agreed that pressure group is one of challenges facing planning of higher institutions.

Concerning challenges facing planning of planning of higher institutions, the result collected revealed in table two item six showed that inadequate planning is one of challenges facing planning of higher institutions. This implies that the majorities of the respondents agreed that inadequate planning is one of challenges facing planning of higher institutions. Nwachukwu (2013) observes that there is a popular saying that "he or she who has failed to plan has planned to fail". Education planning in Nigeria has always been inadequate in line with the enormous facing our educational system. The lack of effective planning poses a significant obstacle to the advancement of education across the country. The success of any educational system hinges on proper planning. Planning of human and material resources has evolved to guide the allocation and utilisation of educational resources in the school systems. Such planning is required to arrest areas of wasted resources and to make educational production more successful. Consequently, for any educational system to truly develop, effective planning is indispensable as education and planning are essential characteristics for effective education (Ololube, 2013).

The result obtained in table two item seven showed that poor capacity of planner is one of challenges facing planning of higher institutions. This implies that the majorities of the respondents agreed that poor capacity of planner is one of challenges facing planning of higher institutions. Nwachukwu (2013) submits that most educational planners in Nigerian do not have complete competence in planning. Qualified planners are the single most significant resource that can lead to greater and efficient planning productivity and performance. In planning, what is needed is the effective utilisation resources by connecting the totality knowledge, skills and talents to achieve planning objectives. The quality of planners should not be nothing less than the basic acceptable standards worldwide.

\section{Conclusion}

This study is aimed to investigate the challenges facing planning of higher institutions in Federal Capital Territory, Abuja, Nigeria. Specific objectives are to:

1. To establish if there are challenges facing planning of higher education

2. To find out the challenges facing the planning of higher education

Result collected and analyzed revealed that there is significant relationship between planning of higher education and challenges. This result also showed that political influence, political instability, inadequate data, inadequate fund to plan, pressure group, inadequate 
planning and poor capacity of planner are the challenges facing the planning of higher education in Federal Capital Territory, Abuja.

Based on the findings, the following were recommended:

1. The government should increase the budgetary allocation for educational planning in the country.

2. The politicians should allow planners do their work objectives and should not influence their planning.

3. Successful government in power should imbibe the political will of continue the former administration educational plan

4. The government should restructure the various agencies saddled with the responsibilities of data generation and management in the country so that creditable data/information will be made available for planning.

5. The government should design a training programme for educational planners. This will help the planners to improve on their planning techniques and skills

\section{Limitations}

This research is only limited to F.C.T, Abuja, this limit its generalization. The study is also limited because this area of research is new there is no secondary data.

\section{Acknowledgment/Ucapan Terima Kasih}

[].

\section{References/Referensi}

Federal Ministry of Education (2004). National Policy on Education. Abuja: FME.

Adeyemi, K. (2001). Equality of Access and Catchment Area; Factor in, University Admission in Nigeria, Journal of Higher Education, 42, 307 -322.

Obanya, P. (1999). Higher Education for an Emergent Nigeria: Faculty of Education, University of Ibadan 5th Anniversary Lecture, Ibadan. Heinemann Education Books (Nigeria PIc)

Noun (2007). Issues and Problems of Higher Education. Lagos

NEEDS (2014). Needs assessment in the Nigerian education sector international organization for migration Abuja, Nigeria

Moja, T. (2000). Nigeria Education Sector Analysis: An Analytical Synthesis of Performance and Main Issues. New York: World Bank.

Longe, R. S. (2003). Introduction to educational planning. in Babalola, J. B (ed) Basic Text in Educational planning, Ibadan: Department of Educational Management, University of Ibadan, 1-34.

Akpan, C. P. (2000). Effective planning: A pre-requisite for successful implementation of the Universal Basic Education (UBE) scheme. International Journal of Research in Basic and Life-Long Education, 1(182), 103-109.

Dror, Y. (1963). The planning process. International Review of Administrative Sciences, 29(1), 46-58.

Aghenta, J. A. (1993). Principles and practice of educational planning: Focus on the developing Countries. Benin City: NSEP. 
Noun. (2007a). Implementation of educational policy plans. Lagos

Adepoju, T. L. (2000). Planning for an effective Educational Policy in Nigeria. A planner's view. In J. O. Fadipe and E. E. Oluchu Kwu (ed). Educational Planning and Administration in Nigeria in the 21st century. Ibandan, NIEPA.

Ogundele, A. (2004). Planning an Effective Educational Programme for Nigerian Schools. Ibadan: Tony Ben Publishers.

James, O., \& Victor, O. E. (2015). Strategic Plan and Implementation of Academic Programme in Unity Schools in South-South, Nigeria. International Journal of Education and Research, 3(8).

Amuchie, A. A., Asotibe, N., \& Christina, T. A. (2013). An Appraisal of the Universal basic Education in Nigeria. Global Journal of Management and Business Research Administration and Management, 13(11).

Ogunode, N. J. (2009). Educational planning in Nigeria. Abuja. Unpublished article

Adarnaechi, B. C., \& Romaine, H. A. (2000). Issues, problems and prospects of free compulsory and qualitative Education in Nigeria. Onitsha: Nigeria Educational Publishers Ltd.

Edame, G. E. (2015). Planning as an instrument for national development in Nigeria. Global Journal of Management and Business Research in Economics and Commerce. 15(4), 15-20.

Otive, I. (2017). An Overview Of Service Delivery Initiative: 12 Years After. Paper presented at the national policy dialogue on strategies for improving service delivery in government parasatals, agencies and commissions in nigeria at state house, abuja on $27^{\text {th }}$ march, 2017.

Nwachukwu, P. O. (2013). The Problems and Approaches to Educational Planning in Nigeria: A Theoretical Observation. Mediterranean Journal of Social Sciences. MCSER Publishing, Rome-Italy

Ekundayo, H. T., \& Ajayi, A. (2009). Towards effective management of university education in Nigeria. International NGO Journal, 4(8), 342-347.

Mahabub, M. G. (2014). The Challenges of Access to University Education in Nigeria. International Conference on Economics, Education and Humanities (ICEEH'14) Dec. 10-11.

Charles C. N., \& Chukwugozie, D. N. (2016). Higher education and general studies in Nigeria: a philosophical investigation. Mgbakoigba, Journal of African Studies, 6(1).

Boniface, N., Alfred, O., \& Dieudonné, T. (2019). Monitoring and Evaluation Practices and Academic Staff Motivation: Implications in Higher Education Within RwandanContext. SAGE

Ade, A. J. F. (2003). Position paper presented at the University Stakeholders National consultative forum, Abuja Federal Ministry of Education March

Ololube, N. P. (2013). Educational management, Planning and Supervision: Models for Effective Implementation. Owerri, Nigeria: Spring Field Publishers.

Coombs, P. (1970) What is educational planning? UNESCO: IIEP. 